\title{
PEOPLE of FAITH
}





\section{PEOPLE of FAITH}

Religious Conviction in American

Journalism and Higher Education

\section{John Schmalzbaver}

Cornell University Press · Ithaca and London 
Chapter 3 appeared in a slightly different form in John Schmalzbauer, "Between Professional and Religious Worlds: Catholics and Evangelicals in American Journalism," Sociology of Religion 60(4): 363-386. Copyright ( 1999 Association for the Sociology of Religion, Inc. All rights reserved.

\section{Copyright $(\mathcal{C} 2003$ by Cornell University}

All rights reserved. Except for brief quotations in a review, this book, or parts thereof, must not be reproduced in any form without permission in writing from the publisher. For information, address Cornell University Press, Sage House, 512 East State Street, Ithaca, New York 14850.

First published 2003 by Cornell University Press

Printed in the United States of America

\section{Library of Congress Cataloging-in-Publication Data}

Schmalzbauer, John Arnold, 1968-

People of faith : religious conviction in American journalism and higher education / John Schmalzbauer.

p. $\mathrm{cm}$.

Includes bibliographical references and index.

ISBN 0-8014-3886-1 (alk. paper)

1. Sociology, Christian-United States. 2. Journalists-Religious life-United States. 3. College teachers--Religious life-United States. 4. Social scientistsReligious life-United States. I. Title.

\section{BR517.S32 2002}

$200^{\prime} .88^{\prime} 097-\mathrm{dc} 21$

2002005771

Cornell University Press strives to use environmentally responsible suppliers and materials to the fullest extent possible in the publishing of its books. Such materials include vegetable-based, low-VOC inks and acid-free papers that are recycled, totally chlorine-free, or partly composed of nonwood fibers. For further information, visit our website at www.cornellpress.cornell.edu.

$\begin{array}{lllllllllll}\text { Cloth printing } & 10 & 9 & 8 & 7 & 6 & 5 & 4 & 3 & 2 & 1\end{array}$ 
For Evelyn Viken, 1913-2001, and for Susan 
